\title{
The effect of branding on consumer palatability ratings of beef strip loin steaks ${ }^{1,2}$
}

\author{
A. K. Wilfong, K. V. McKillip, J. M. Gonzalez, \\ T. A. Houser, J. A. Unruh, E. A. E. Boyle, and T. G. O'Quinn ${ }^{3}$ \\ Department of Animal Sciences and Industry, Kansas State University, Manhattan 66506
}

\begin{abstract}
The objective of this study was to determine the influence of knowing the brand or USDA grade on consumer palatability ratings of beef strip loin steaks. Strip loins were selected to represent 5 USDA grades and brands, USDA Select, Choice, Prime, Certified Angus Beef (CAB; upper 2/3 Choice), and Select, from carcasses of cattle classified as Angus on the basis of phenotype. After $21 \mathrm{~d}$ of aging, 2.5-cmthick steaks were cut, consecutively cut steaks were paired for consumer evaluation. Consumer panelists $(n=112)$ evaluated samples for tenderness, juiciness, flavor liking, and overall liking. Additionally, consumers rated each palatability trait as either acceptable or unacceptable. Samples were fed in 2 rounds on the same day: blind and informed testing. In the first round, blind testing, consumers were served 1 sample from each treatment, with no product information provided. In the second round, consumers were informed of the brand or quality grade prior to sampling. During blind testing, $\mathrm{CAB}$ rated similar $(P>0.05)$ to Choice for all palatability traits; however, $\mathrm{CAB}$ rated greater
\end{abstract}

$(P<0.05)$ than Choice for all traits during informed testing. Additionally, Angus Select and Select were rated similar $(P>0.05)$ for all traits when tested blind, but Angus Select was rated greater $(P<0.05)$ than Select for flavor and overall liking when brand was declared. When comparing blind and informed ratings, Angus Select and $\mathrm{CAB}$ had greater $(P<0.05)$ ratings for juiciness, flavor liking, and overall liking, and Prime had increased $(P<0.05)$ ratings for flavor liking and overall liking because of brand disclosure. However, ratings for Choice and Select samples were unaffected $(P>0.05)$ when brand was disclosed. Brand knowledge increased $(P<0.05)$ the percentage of Prime samples rated as acceptable for flavor and the percentage of Angus Select samples rated as acceptable for flavor and overall liking. Conversely, there was no difference $(P>0.05)$ in the percentage of Choice and Select samples rated as acceptable for all palatability traits. These data indicate that Prime, $\mathrm{CAB}$, and Angus Select steaks receive an increase in consumer palatability perception, or "brand lift," which does not occur for Choice and Select beef.

Key words: Angus, beef, branding, consumer, marbling, palatability

(C) 2016 American Society of Animal Science. All rights reserved.

J. Anim. Sci. 2016.94:4930-4942

doi:10.2527/jas2016-0893

\section{INTRODUCTION}

Results of the National Retail Meat Case Study have shown that the percentage of branded beef products has increased from $42 \%$ in 2004 to $96 \%$ in 2015 (National Cattlemen's Beef Association et al., 2010; Kelly, 2016). This percentage has grown as

\footnotetext{
${ }^{1}$ Funded by the Angus Foundation, 3201 Frederick Ave., St. Joseph, MO 64506.

${ }^{2}$ Contribution number 17-018-J of the Kansas Agricultural Experiment Station, Manhattan, KS 66506.

${ }^{3}$ Corresponding author: travisoquinn@ksu.edu

Received August 10, 2016.

Accepted August 28, 2016.
}

retailers work to capture added value through product differentiation and branding. Today, the USDA Agricultural Marketing Service monitors and certifies product for 108 different Certified Beef programs (USDA, 2016a), of which 76 include "Angus" as part of the brand name or as a breed-specific product specification (USDA, 2016a). This large number of Angus programs attempts to capture value created by the success of Certified Angus Beef (CAB).

Numerous studies have demonstrated the economic value of branded beef programs (Feldkamp et al., 2005; Parcell and Schroeder, 2007; Schulz et al., 2012). Also, it is well documented that beef products with increased marbling levels result in greater consumer eating satisfaction (Savell et al., 1987; 
O’Quinn et al., 2012; Corbin et al., 2015). However, no previous studies have evaluated the palatabilityrelated value of beef branding. Most published reports detailing beef palatability differences are the result of "blind" consumer testing in which panelists are not informed of the product type before evaluation, but consumer purchasing decisions and product evaluation in real-world settings are not blind. Consumers are often aware of the brand, grade, and numerous other factors before they ever take their first bite. Consumer evaluations of beer, hazelnut cocoa spreads, and spaghetti noodles have previously been shown to be impacted by branding (Allison and Uhl, 1964; Di Monaco et al., 2004; Della Lucia et al., 2014; Spinelli et al., 2015), although no such study has evaluated beef.

Therefore, the objective of this study was to determine the effect of branding on consumer perceptions of beef steak palatability and determine the palatability-related value associated with USDA grade, CAB, and Angus branding.

\section{MATERIALS AND METHODS}

\section{Steak Treatments and Preparation}

Beef strip loins (Institutional Meat Purchasing Specifications \#180; North American Meat Processors Association, 2010) were selected to equally represent ( $n=40 ; 8 /$ brand; 1 per carcass) 5 USDA grades and brands: USDA Select, Choice (USDA marbling scores of Small ${ }^{00}$ to Small ${ }^{100}$ ), Prime, CAB, and Select from phenotypical Angus cattle (Angus Select). Angus Select strip loins were obtained from carcasses of cattle that had been classified as Angus on the basis of phenotype (Schedule GLA; USDA, 2016b), whereas the Select product was selected from carcasses with no apparent dairy or Bos indicus influence that was not identified as phenotypical Angus. All included carcasses were selected on the basis of rib eye area $\left(25.4\right.$ to $\left.40.6 \mathrm{~cm}^{2}\right)$, fat thickness $(<2.54 \mathrm{~cm})$, and $\mathrm{HCW}$ $(<477 \mathrm{~kg}$ ) consistent with CAB specifications. Product was selected by trained Kansas State University (KSU) personnel from a commercial beef processor in Nebraska. Upon selection, the research team recorded USDA marbling score, carcass lean and skeletal maturity, rib eye area, fat thickness, HCW, and the percentage of KPH (data not reported). Strip loins were vacuum packaged and transported under refrigeration $\left(2^{\circ} \mathrm{C}\right)$ to the KSU Meat Laboratory (Manhattan, KS), where they were aged at $0^{\circ} \mathrm{C}$ to $4^{\circ} \mathrm{C}$ for $21 \mathrm{~d}$ postmortem prior to steak fabrication.

Following aging, strip loins were trimmed to remove external fat and fabricated into 2.5 -cm-thick steaks. The most anterior "wedge" steak was cut and used for color and $\mathrm{pH}$ analysis. Wedge steaks were placed on trays with the fresh cut surface exposed to oxygen, covered from light with butcher paper, and allowed to bloom for 15 min. After blooming, CIE L*, $\mathrm{a}^{*}$, and $\mathrm{b}^{*}$ were measured 3 times on each steak using a Hunter Lab Miniscan EZ spectrophotometer (Illuminant A, 2.54-cm-diam. aperture, $10^{\circ}$ observer; Hunter Associates Laboratory, Reston, VA), and the 3 readings were averaged for each steak. Steak $\mathrm{pH}$ was measured using a $\mathrm{pH}$ meter (model HI 99163; Hanna Instruments, Smithfield, RI) immediately following color measurement. Following color and $\mathrm{pH}$ measurement, wedge steaks were frozen $\left(-20^{\circ} \mathrm{C}\right)$ for proximate analysis.

The remaining loin was fabricated into steaks from anterior to posterior, and steaks were designated for Warner-Bratzler shear force testing (WBSF; steaks 1 and 8) or paired for consumer blind and informed sampling (paired steaks 2 and 3, paired steaks 9 and 10). Following fabrication, steaks were weighed (raw weight), individually vacuum packaged, and frozen $\left(-20^{\circ} \mathrm{C}\right)$ until subsequent analysis.

\section{Consumer Panel Testing}

The KSU Institutional Review Board approved procedures for use of human subjects for sensory panel evaluations (IRB \#7440). Consumer testing was conducted at the KSU Animal Science Building (Manhattan, $\mathrm{KS})$. Consumer panelists $(n=112)$ were recruited from Manhattan, KS, and the surrounding communities, were paid to participate in the study, and were allowed to participate only 1 time. Consumer sampling was conducted in a large room, under fluorescent lighting. Five panel sessions were conducted with 21 consumers, and 1 panel session was conducted with 7 consumers. Each panel lasted approximately $1.5 \mathrm{~h}$.

Steaks were thawed at $2^{\circ} \mathrm{C}$ to $4^{\circ} \mathrm{C}$ for $24 \mathrm{~h}$ prior to consumer testing. Prior to cooking, thawed steaks were weighed for determination of thaw loss. Steaks were cooked to a medium $\left(71^{\circ} \mathrm{C}\right)$ degree of doneness at $163^{\circ} \mathrm{C}$ in a convection oven (DFG-100-3 Series, GS Blodgett Co. Inc., Burlington, VT) with cooked temperature monitored, using thermocouples attached to a Doric Mini-trend Data Logger (model 205 B-1-c OFT, Doric Scientific, San Diego, CA) and verified by probe thermometers (model 450-ATT, Omega Engineering, Stamford, CT). After cooking and weighing for cook loss determination, steaks were cut into $1.3 \mathrm{~cm}^{2} \times 2.54$ $\mathrm{cm}$ cubes, and 2 cubes were immediately served to 7 predetermined consumers.

Consumers were provided utensils, an expectorant cup, a ballot, and palate cleansers to use between samples (unsalted crackers and apple juice). Prior to the start of each panel session, panelists were given 


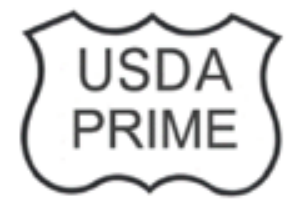

Prime

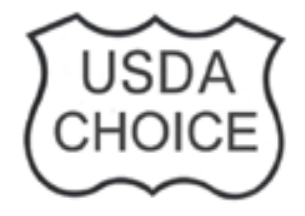

Choice

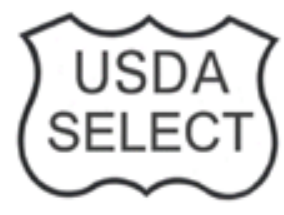

Select

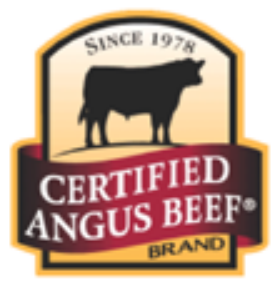

Certified Angus Beef
Angus Select

\section{Angus Select}

Figure 1. Brand labels used to identify USDA grade and brand treatments to consumers during informed consumer testing.

verbal instructions explaining the ballot, testing procedures, and use of palate cleansers. The ballot included a brief demographic questionnaire used to characterize gender, household size, income level, education level, ethnicity, and beef consumption habits. Additionally, consumers were asked to complete a beef brand awareness questionnaire, identifying their knowledge of USDA grades and brands and the perceived quality level associated with known USDA grades and brands. Also, a beef purchasing motivator questionnaire was presented prior to sample evaluation that asked consumers to rate the importance of multiple fresh beef steak purchasing motivators.

Serving of samples was conducted in 2 rounds. In the first round, consumers were served 1 sample from each treatment in a random order, blind (i.e., panelists were only informed that all samples evaluated were beef steaks). Each sample was evaluated for tenderness, juiciness, flavor liking, and overall liking on 100$\mathrm{mm}$ line scales anchored at both ends and midpoints with descriptive terms: $100=$ extremely juicy, tender, and like extremely; $50=$ neither tough nor tender, juicy, and neither dislike or like; $0=$ extremely tough, dry, and dislike extremely. Moreover, consumers rated each palatability trait as either acceptable or unacceptable and classified the sample as unsatisfactory, everyday quality, better than everyday, or premium quality.

Following completion of the first round, all ballots were collected, and consumers received a new ballot for evaluation of samples during the second round of testing. Testing procedures for round 2 were identical to round 1 ; however, prior to the serving of each sample, consumers were given a description of the product to be tested. Consumers were informed of the brand of the product (Select, Choice, Prime, CAB, or Angus Select) prior to evaluation of each sample verbally and with a label of the brand printed on their ballot sheets (Fig. 1). Additionally, the brand label to be evaluated was presented to consumers in front of the room on a projection screen. Samples evaluated in round 2 were paired with samples from round 1 , allowing for a direct comparison of consumer ratings and evaluation of the effects of branding and grade identification on palatability perception.

\section{Warner-Bratzler Shear Force}

Steaks for WBSF testing were prepared and cooked as previously described for consumer testing. Following cooking, samples were allowed to temper $\left(2^{\circ} \mathrm{C}\right.$ to $\left.4^{\circ} \mathrm{C}\right)$ overnight. For WBSF testing, six $1.27-\mathrm{cm}$-diam. core samples were removed from each steak parallel to the muscle fiber orientation. Each core was sheared (crosshead speed of $250 \mathrm{~mm} / \mathrm{min}$ ) once through the center, perpendicular to the muscle fibers using an INSTRON model 5569 testing machine (Instron, Canton, MA). Shear force values were recorded in kilograms, and the shear force values of the 6 cores were averaged for each steak.

\section{Proximate Analysis}

Frozen steaks for proximate analysis were thawed for $24 \mathrm{~h}$ at $2^{\circ} \mathrm{C}$ to $4^{\circ} \mathrm{C}$. All exterior fat was removed, leaving only the LM for analysis. Each sample was frozen in liquid nitrogen and homogenized using a commercial 4-blade blender (model 33BL 79, Waring Products, New Hartford, CT) and then transferred to Whirl-Pac bags (Nasco, Ft. Atkinson, WI) and stored $\left(-20^{\circ} \mathrm{C}\right)$ until subsequent analysis. Moisture content was determined by microwave radiation (CEM Corp.) with a SMART Trac Fat and Moisture Analyzer using the protocols described by AOAC official methods (method 985.14 (A2)). Crude protein was determined using a LECO TruMac N analyzer (St. Joseph, MI; AOAC, 2005). A modified Folch method was used for fat percentage analysis using methods described by Martin et al. (2013). Ash percentage was determined using a muffle furnace following the methods of AOAC (2005). 
Table 1. Warner-Bratzler shear force values, proximate composition, $\mathrm{L}^{*}, \mathrm{a}^{*}, \mathrm{~b}^{*}, \mathrm{pH}$, and moisture losses for strip loin steaks of differing treatments

\begin{tabular}{|c|c|c|c|c|c|c|c|c|c|c|c|c|}
\hline Treatment & $\begin{array}{l}\text { Warner-Bratzler } \\
\text { shear force, } \mathrm{kg}\end{array}$ & Moisture, ${ }^{0}$ & Protein, \% & Fat, \% & Ash, $\%$ & $\mathrm{~L}^{* 1}$ & $a^{* 2}$ & $b^{* 3}$ & $\mathrm{pH}$ & $\begin{array}{c}\text { Thaw } \\
\text { loss, }{ }^{4} \%\end{array}$ & $\begin{array}{l}\text { Cooking } \\
\text { loss }, 5 \%\end{array}$ & $\begin{array}{c}\text { Total loss, } \\
\%\end{array}$ \\
\hline Prime & $2.1^{\mathrm{c}}$ & $66.7^{\mathrm{c}}$ & 22.0 & $8.9^{\mathrm{a}}$ & 1.3 & $49.5^{\mathrm{a}}$ & 25.9 & 19.3 & 5.6 & $1.8^{\mathrm{c}}$ & $20.2^{\mathrm{b}}$ & $22.4^{\mathrm{b}}$ \\
\hline Certified Angus Beef & $2.7^{\mathrm{b}}$ & $69.7^{\mathrm{b}}$ & 22.5 & $5.4^{\mathrm{b}}$ & 1.4 & $43.7^{\mathrm{b}, \mathrm{c}}$ & 27.4 & 19.2 & 5.7 & $2.0^{\mathrm{c}}$ & $21.9^{\mathrm{a}, \mathrm{b}}$ & $24.2^{\mathrm{a}, \mathrm{b}}$ \\
\hline Choice & $2.7^{\mathrm{b}}$ & $71.2^{\mathrm{a}}$ & 23.0 & $3.7^{\mathrm{c}}$ & 1.4 & $44.4^{\mathrm{b}}$ & 26.8 & 19.0 & 5.6 & $2.2^{\mathrm{b}, \mathrm{c}}$ & $23.0^{\mathrm{a}}$ & $25.9^{\mathrm{a}}$ \\
\hline Select & $3.0^{\mathrm{a}, \mathrm{b}}$ & $72.2^{\mathrm{a}}$ & 22.3 & $2.7^{\mathrm{c}}$ & 1.4 & $44.1^{\mathrm{b}}$ & 26.6 & 18.4 & 5.6 & $2.8^{\mathrm{a}}$ & $23.2^{\mathrm{a}}$ & $26.2^{\mathrm{a}}$ \\
\hline Angus Select & $3.1^{\mathrm{a}}$ & $71.9^{\mathrm{a}}$ & 22.5 & $2.9^{\mathrm{c}}$ & 1.4 & $40.8^{\mathrm{c}}$ & 26.0 & 17.5 & 5.8 & $2.5^{\mathrm{a}, \mathrm{b}}$ & $23.4^{\mathrm{a}}$ & $26.0^{\mathrm{a}}$ \\
\hline $\mathrm{SEM}^{7}$ & 0.1 & 0.5 & 0.4 & 0.4 & 0.1 & 1.2 & 0.5 & 0.6 & 0.1 & 0.1 & 0.7 & 0.8 \\
\hline$P$-value & $<0.01$ & $<0.01$ & 0.34 & $<0.01$ & 0.54 & $<0.01$ & 0.26 & 0.24 & 0.39 & $<0.01$ & $<0.01$ & $<0.01$ \\
\hline
\end{tabular}

${ }^{\mathrm{a}-\mathrm{C}}$ Least squares means in the same column lacking a common superscript $\operatorname{differ}(P<0.05)$.

${ }^{1} \mathrm{~L}^{*}=$ lightness $(0=$ black and $100=$ white $)$.

$2 a^{*}=$ redness $(-60=$ green and $60=$ red $)$.

${ }^{3} \mathrm{~b}^{*}=$ blueness $(-60=$ blue and $60=$ yellow $)$.

${ }^{4}$ Thaw loss: [(raw weight - thaw weight $) /$ raw weight $] \times 100$.

${ }^{5}$ Cooking loss: [(thaw weight - cooked weight)/thaw weight $] \times 100$.

${ }^{6}$ Total loss: [(raw weight - cooked weight $) /$ raw weight $] \times 100$.

${ }^{7} \mathrm{SE}$ (largest) of the least squares means.

\section{Statistical Analyses}

Statistical analyses were conducted in SAS (version 9.4; SAS Inst. Inc., Cary, NC) using PROC GLIMMIX with $\alpha=0.05$. The model for WBSF included the fixed effect of brand, and steak peak cooking temperature was included in the model as a covariate. For all consumer panel data, the model included the fixed effect of brand and the random effect of panel session number. Additionally, all acceptability data were analyzed with a model that included a binomial error distribution. Demographic data were summarized using PROC FREQ. Moreover, the KenwardRoger approximation was used for estimating denominator degrees of freedom for all consumer panel, WBSF, and proximate data analyses.

\section{RESULTS}

\section{Color, Proximate, Percentage Moisture Loss, and Warner-Bratzler Shear Force Measurements}

Color, $\mathrm{pH}$, proximate analysis, percentage moisture loss, and WBSF data are shown in Table 1. For color readings, $\mathrm{a}^{*}$ and $\mathrm{b}^{*}$ values were not different $(P>0.05)$ among treatments. However, $L^{*}$ readings for Prime were the greatest $(P<0.05)$, indicating Prime samples were lighter in color than all other treatments. Angus Select steaks were darker $(P<0.05)$ than all treatments other than $\mathrm{CAB}$. Choice, $\mathrm{CAB}$, and Select samples were similar $(P>0.05)$ for $\mathrm{L}^{*}$ value. No differences $(P$ $>0.05$ ) among treatments for $\mathrm{pH}$ were observed.

Proximate analysis data indicated no difference $(P>$ $0.05)$ among quality treatments for protein and ash percentages; however, differences $(P<0.05)$ were found among treatments for fat and moisture percentage. As quality grade decreased from Prime to Select, moisture percentage increased by $5.5 \%$. Additionally, Choice, Select, and Angus Select treatments were similar $(P>$ $0.05)$ for both moisture and fat percentage. Prime had the greatest $(P<0.05)$ amount of fat at $8.9 \%$, followed by $\mathrm{CAB}$ at $5.4 \%$. Choice samples had, on average, $0.8 \%$ to $1.0 \%$ more fat than Angus Select and Select samples, respectively; however, fat percentages for these treatments did not differ $(P>0.05)$ statistically.

Analysis of WBSF indicated Prime samples were the most tender $(P<0.05)$. Additionally, Choice, Select, and CAB treatments were similar $(P>0.05)$ for WBSF, with Angus Select samples found to be tougher $(P<0.05)$ than all treatments, other than Select.

Cooking and total loss percentages were similar $(P>0.05)$ among all treatments with the exception of Prime, which had a lower $(P<0.05)$ cooking and total loss percentage than Select, Angus Select, and Choice steaks. Select steaks had a greater $(P<0.05)$ amount of thaw loss than all treatments other than Angus Select, with no differences $(P>0.05)$ found among Prime, $\mathrm{CAB}$, and Choice for thaw loss percentage.

\section{Demographic, Brand Awareness, and Purchasing Motivators}

The demographic profile of consumer panelists who participated in the study is presented in Table 2. A majority $(57.8 \%)$ of consumer panelists were female, and $42.2 \%$ were male. Panelists' ages ranged from under $20 \mathrm{yr}$ old to over $60 \mathrm{yr}$ old, with a majority $(60.0 \%)$ within an age range of 20 to $49 \mathrm{yr}$ old. A large percentage of consumers who participated in 
Table 2. Demographic characteristics of consumers $(n=112)$ who participated in steak sensory panels

\begin{tabular}{|c|c|c|}
\hline Characteristic & Response & $\begin{array}{c}\text { Percentage of } \\
\text { consumers }\end{array}$ \\
\hline \multirow[t]{2}{*}{ Sex } & Male & 42.2 \\
\hline & Female & 57.8 \\
\hline \multirow[t]{7}{*}{ Household size } & 1 person & 9.9 \\
\hline & 2 people & 17.1 \\
\hline & 3 people & 16.2 \\
\hline & 4 people & 32.4 \\
\hline & 5 people & 8.1 \\
\hline & 6 people & 13.5 \\
\hline & $>6$ people & 2.7 \\
\hline \multirow[t]{2}{*}{ Marital status } & Single & 33.0 \\
\hline & Married & 67.0 \\
\hline \multirow[t]{6}{*}{ Age group } & Under 20 & 9.0 \\
\hline & $20-29$ & 29.0 \\
\hline & $30-39$ & 18.2 \\
\hline & $40-49$ & 21.8 \\
\hline & $50-59$ & 18.2 \\
\hline & $>60$ & 3.6 \\
\hline \multirow[t]{4}{*}{ Ethnic origin } & African American & 15.6 \\
\hline & Caucasian/white & 72.5 \\
\hline & Hispanic & 10.0 \\
\hline & Native American & 1.8 \\
\hline \multirow{5}{*}{$\begin{array}{l}\text { Annual household } \\
\text { income, \$ }\end{array}$} & 25,000 to 34,999 & 14.4 \\
\hline & 35,000 to 49,999 & 8.1 \\
\hline & 50,000 to 74,999 & 23.4 \\
\hline & 75,000 to 100,000 & 27.9 \\
\hline & $>100,000$ & 26.1 \\
\hline \multirow{4}{*}{$\begin{array}{l}\text { Highest level of } \\
\text { education completed }\end{array}$} & High school graduate & 9.5 \\
\hline & Some college/technical school & 27.6 \\
\hline & College graduate & 34.3 \\
\hline & Postgraduate & 28.6 \\
\hline \multirow{3}{*}{$\begin{array}{l}\text { Weekly beef } \\
\text { consumption }\end{array}$} & 1 to 3 times & 47.8 \\
\hline & 4 to 6 times & 46.9 \\
\hline & 7 or more times & 5.4 \\
\hline \multirow{3}{*}{$\begin{array}{l}\text { Most important palat- } \\
\text { ability trait when } \\
\text { eating beef }\end{array}$} & Flavor & 49.6 \\
\hline & Juiciness & 9.9 \\
\hline & Tenderness & 40.5 \\
\hline \multirow{9}{*}{$\begin{array}{l}\text { Meat product most } \\
\text { preferred for flavor }\end{array}$} & Beef & 63.1 \\
\hline & Chicken & 18.0 \\
\hline & Fish & 5.4 \\
\hline & Lamb & 0.9 \\
\hline & Pork & 5.4 \\
\hline & Shellfish & 3.6 \\
\hline & Turkey & 0.0 \\
\hline & Veal & 0.9 \\
\hline & Venison & 2.7 \\
\hline
\end{tabular}

the panels were married (67.0\%) and Caucasian/white $(72.5 \%)$. The majority of consumers $(>75 \%)$ had an annual household income of at least $\$ 50,000$, and over half of participants $(>60 \%)$ were also at least a college graduate, with $28.6 \%$ of consumers having completed postgraduate education. Nearly half $(47.8 \%)$ of con-
Table 3. Fresh beef steak purchasing motivators of consumers $(n=112)$ who participated in consumer sensory panels

\begin{tabular}{lc}
\hline \hline Characteristic & $\begin{array}{c}\text { Importance of } \\
\text { trait }\end{array}$ \\
\hline Price & $74.4^{\mathrm{a}}$ \\
Steak color & $74.2^{\mathrm{a}}$ \\
Size, weight and thickness & $71.3^{\mathrm{a}}$ \\
USDA Grade & $63.9^{\mathrm{b}}$ \\
Marbling level & $62.9^{\mathrm{b}}$ \\
Familiarity of cut & $58.7^{\mathrm{b}, \mathrm{c}}$ \\
Eating satisfaction claims (e.g., guaranteed tender) & $54.2^{\mathrm{c}, \mathrm{d}}$ \\
Nutrient content & $52.7^{\mathrm{c}, \mathrm{d}}$ \\
Country of origin & $51.6^{\mathrm{d}}$ \\
Animal welfare & $49.2^{\mathrm{d}, \mathrm{e}}$ \\
Local & $49.1^{\mathrm{d}, \mathrm{e}}$ \\
Antibiotic use in the animal & $47.8^{\mathrm{d}, \mathrm{e}, \mathrm{f}}$ \\
Growth promotant use in the animal & $42.4^{\mathrm{e}, \mathrm{f}}$ \\
Natural and organic claims & $41.3^{\mathrm{f}}$ \\
Brand of product & $41.0^{\mathrm{f}}$ \\
SEM & $2.5^{2}$ \\
$P$-value & $<0.01$ \\
\hline a-f Least squares means lacking a common superscript differ $(P<0.05)$. \\
1Purchasing motivators: $0=$ extremely unimportant, $100=$ extremely \\
important. & \\
2SE (largest) of the least squares means. &
\end{tabular}

sumers consumed beef 1 to 3 times a week, and 63.1\% considered beef the meat with the most preferred flavor. Flavor was the most important palatability trait when eating steaks for $49.6 \%$ of consumers, with tenderness the most important trait for $40.5 \%$ and juiciness most important for $9.9 \%$ of consumers.

Consumers were asked to rate the importance of 15 different fresh beef steak purchasing motivators on a scale from extremely unimportant to extremely important (Table 3). For the consumers in this study, the most important $(P<0.05)$ traits when purchasing beef included price, steak color, and size, weight, and thickness. Additionally, USDA grade and marbling were rated more $(P<0.05)$ important than animal welfare, nutrient content, local, eating satisfaction claims, and country of origin. However, the claims of animal welfare, nutrient content, local, eating satisfaction claims, and country of origin were rated more $(P<0.05)$ important than natural and organic claims and brand of product.

When asked to identify and rate the perceived quality of 9 beef USDA grades and brands, 4 of the USDA grades and brands (Select, Choice, Prime, and CAB) had greater than $79 \%$ of consumers indicate they had knowledge of the brand, each with a higher $(P<0.05)$ percentage than all other USDA grades and brands included in the survey (Table 4). Also, less than $10 \%$ of consumers indicated knowledge of the brands Black Canyon Angus Beef, Creekstone Farms, 
Table 4. Brand and USDA grade knowledge and perceived brand quality level of consumers $(n=112)$ who participated in sensory panels

\begin{tabular}{lcc}
\hline \hline & $\begin{array}{c}\text { Consumers with } \\
\text { knowledge of brand, } \\
\%\end{array}$ & $\begin{array}{c}\text { Perceived quality } \\
\text { level by consumers } \\
\text { who recognized the } \\
\text { brand }\end{array}$ \\
Brand & $6.3^{\mathrm{d}}$ & $7.9^{\mathrm{a}, \mathrm{b}, \mathrm{c}}$ \\
\hline Angus Pride & $25.9^{\mathrm{c}}$ & $7.5^{\mathrm{b}, \mathrm{c}}$ \\
Angus Select & $9.8^{\mathrm{d}}$ & $6.9^{\mathrm{c}, \mathrm{d}}$ \\
Black Canyon Angus Beef & $83.0^{\mathrm{a}}$ & $8.1^{\mathrm{a}, \mathrm{b}}$ \\
Certified Angus Beef & $86.5^{\mathrm{a}}$ & $6.4^{\mathrm{d}}$ \\
Choice & $7.2^{\mathrm{d}}$ & $7.1^{\mathrm{b}, \mathrm{c}, \mathrm{d}}$ \\
Creekstone Farms & $80.4^{\mathrm{a}}$ & $8.5^{\mathrm{a}}$ \\
Prime & $66.1^{\mathrm{b}}$ & $7.1^{\mathrm{c}, \mathrm{d}}$ \\
Private Selection & $79.3^{\mathrm{a}}$ & $6.7^{\mathrm{c}, \mathrm{d}}$ \\
Select & $0.4^{2}$ & 0.6 \\
SEM & $<0.01$ & $<0.01$ \\
$P$-value & & \\
\hline
\end{tabular}

${ }^{\mathrm{a}-\mathrm{d}}$ Least squares means in the same column lacking a common superscript differ $(P<0.05)$.

${ }^{1}$ Perceived quality level: 1 = very low quality, $10=$ very high quality.

${ }^{2} \mathrm{SE}$ (largest) of the least squares means.

and Angus Pride. Interestingly, 25.9\% of consumers stated knowledge of the brand "Angus Select," a fictional generic brand that was created for the current study. Moreover, consumers rated this brand simi$\operatorname{lar}(P>0.05)$ in quality level to CAB. Many of the

Table 5. Consumer $(n=112)$ palatability ratings for blind and informed testing of strip loin steaks of various treatments ${ }^{1}$

\begin{tabular}{|c|c|c|c|c|}
\hline Treatment & Tenderness & Juiciness & $\begin{array}{l}\text { Flavor } \\
\text { liking }\end{array}$ & $\begin{array}{c}\text { Overall } \\
\text { liking }\end{array}$ \\
\hline \multicolumn{5}{|l|}{ Blind testing } \\
\hline Prime & $73.7^{\mathrm{a}}$ & $68.7^{\mathrm{a}}$ & $66.9^{\mathrm{a}}$ & $69.4^{\mathrm{a}}$ \\
\hline Certified Angus Beef & $66.2^{\mathrm{a}, \mathrm{b}}$ & $58.2^{\mathrm{b}}$ & $63.2^{\mathrm{a}, \mathrm{b}}$ & $64.2^{\mathrm{a}, \mathrm{b}}$ \\
\hline Choice & $65.0^{\mathrm{b}}$ & $58.1^{\mathrm{b}}$ & $60.7^{b, c}$ & $61.0^{\mathrm{b}, \mathrm{c}}$ \\
\hline Select & $62.1^{\mathrm{b}}$ & $55.9^{\mathrm{b}}$ & $55.2^{\mathrm{c}}$ & $56.0^{\mathrm{c}}$ \\
\hline Angus Select & $58.7^{\mathrm{b}}$ & $54.8^{\mathrm{b}}$ & $57.0^{\mathrm{b}, \mathrm{c}}$ & $56.8^{\mathrm{c}}$ \\
\hline $\mathrm{SEM}^{2}$ & 2.9 & 2.8 & 2.2 & 2.2 \\
\hline$P$-value & $<0.01$ & $<0.01$ & $<0.01$ & $<0.01$ \\
\hline \multicolumn{5}{|l|}{ Informed testing } \\
\hline Prime & $77.9^{\mathrm{a}}$ & $73.7^{\mathrm{a}}$ & $74.4^{\mathrm{a}}$ & $76.3^{\mathrm{a}}$ \\
\hline Certified Angus Beef & $70.0^{\mathrm{a}}$ & $64.1^{\mathrm{b}}$ & $71.2^{\mathrm{a}}$ & $69.8^{\mathrm{b}}$ \\
\hline Choice & $60.3^{\mathrm{b}}$ & $53.9^{\mathrm{c}}$ & $59.9^{\mathrm{c}}$ & $58.6^{\mathrm{c}, \mathrm{d}}$ \\
\hline Select & $55.9^{\mathrm{b}}$ & $56.3^{\mathrm{c}}$ & $59.3^{\mathrm{c}}$ & $57.0^{\mathrm{d}}$ \\
\hline Angus Select & $59.4^{\mathrm{b}}$ & $60.2^{\mathrm{b}, \mathrm{c}}$ & $65.7^{\mathrm{b}}$ & $63.0^{\mathrm{c}}$ \\
\hline $\mathrm{SEM}^{2}$ & 3.1 & 3.2 & 2.0 & 2.3 \\
\hline$P$-value & $<0.01$ & $<0.01$ & $<0.01$ & $<0.01$ \\
\hline
\end{tabular}

${ }^{a-d}$ Least squares means in the same section (blind or informed) of the same column and lacking a common superscript differ $(P<0.05)$.

${ }^{1}$ Sensory scores: $0=$ not tender/juicy, dislike flavor/overall extremely; $50=$ neither tough nor tender, dry nor juicy or neither like or dislike flavor/overall; 100 = very tender/juicy, like flavor/overall extremely.

${ }^{2} \mathrm{SE}$ (largest) of the least squares means.
Angus brands were perceived to have a high quality level associated with them, with all brands containing "Angus" rating 6.9 or greater out of 10 for perceived quality level. Additionally, mean perceived quality of brands and grades ranged from 6.4 to 8.5 out of 10 , indicating consumers considered all of these brands and USDA grades to be better than average quality.

\section{Consumer Palatability Ratings of Beef Strip Loins Steaks}

Consumer palatability ratings of strip loin samples are found in Table 5. During blind testing, Prime rated higher $(P<0.05)$ for tenderness than all other treatments, except CAB. Prime was also rated greatest $(P<0.05)$ for juiciness by consumers in blind evaluation. Tenderness and juiciness of CAB, Choice, Select, and Angus Select were all rated similar $(P>0.05)$ by consumers in blind testing. For flavor liking, Prime and $\mathrm{CAB}$ rated similar $(P>0.05)$ and greater $(P<0.05)$ than Select. Ratings for overall liking followed a pattern similar to that of flavor liking, with Prime rating greater $(P<0.05)$ than all lower grading treatments but similar $(P>0.05)$ to $\mathrm{CAB}$. Consumers rated the overall liking of $\mathrm{CAB}$ similar $(P>$ $0.05)$ to Choice but greater $(P<0.05)$ than the 2 Select treatments. Angus Select strip loin steaks were rated similar $(P>0.05)$ to Select steaks for all palatability traits evaluated during blind testing.

When USDA grades and brands of the treatments were disclosed prior to consumer testing, palatability scores were affected (Table 5). Prime rated greatest $(P$ $<0.05)$ for juiciness and overall liking, with only $\mathrm{CAB}$ rating similar $(P>0.05)$ to Prime for tenderness and flavor liking. Also, $\mathrm{CAB}$ rated greater $(P<0.05)$ than all other treatments other than Prime for tenderness, flavor liking, and overall liking. Additionally, $\mathrm{CAB}$ samples were rated higher $(P<0.05)$ than both Choice and Select samples for all palatability traits. Angus Select samples rated similar $(P>0.05)$ to $\mathrm{CAB}$ for juiciness and greater $(P<0.05)$ than both Choice and Select for flavor liking. During informed testing, Angus Select was rated higher $(P<0.05)$ than Select samples for both flavor liking and overall liking, both of which were similar $(P>0.05)$ for the 2 treatments during blind evaluation.

Figure 2 shows the percentage change in consumer ratings ([consumer informed score - consumer blind score]/consumer blind score) of palatability traits as a result of brand disclosure prior to testing. Angus Select samples had an increase $(P<0.05)$ of $16.5 \%$ for flavor liking scores, and CAB and Prime also had increased $(P$ $<0.05$ ) flavor liking ratings of $14.6 \%$ and $14.7 \%$, respectively. Moreover, juiciness scores increased $(P<0.05)$ for $\mathrm{CAB}(13.6 \%)$ and Angus Select (15.2\%) steaks because of brand disclosure. Overall liking increased $(P$ 


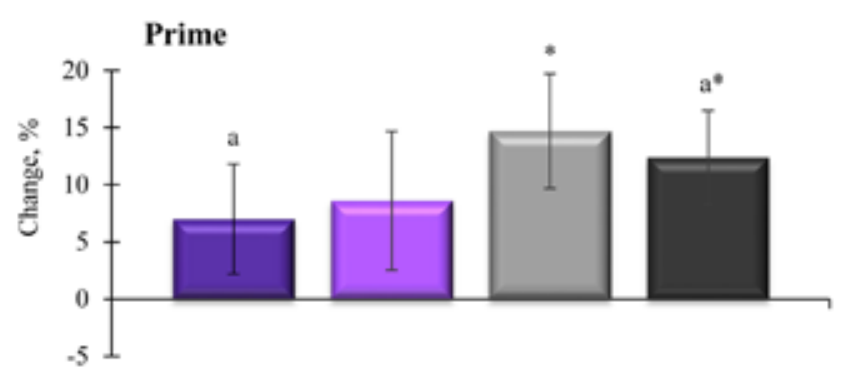

Brand Effect

Tenderness: $P=0.03$

Juiciness: $P=0.06$

Flavor Liking; $P=0.16$

Overall Liking; $P=0.03$

\section{Certified Angus Beef}
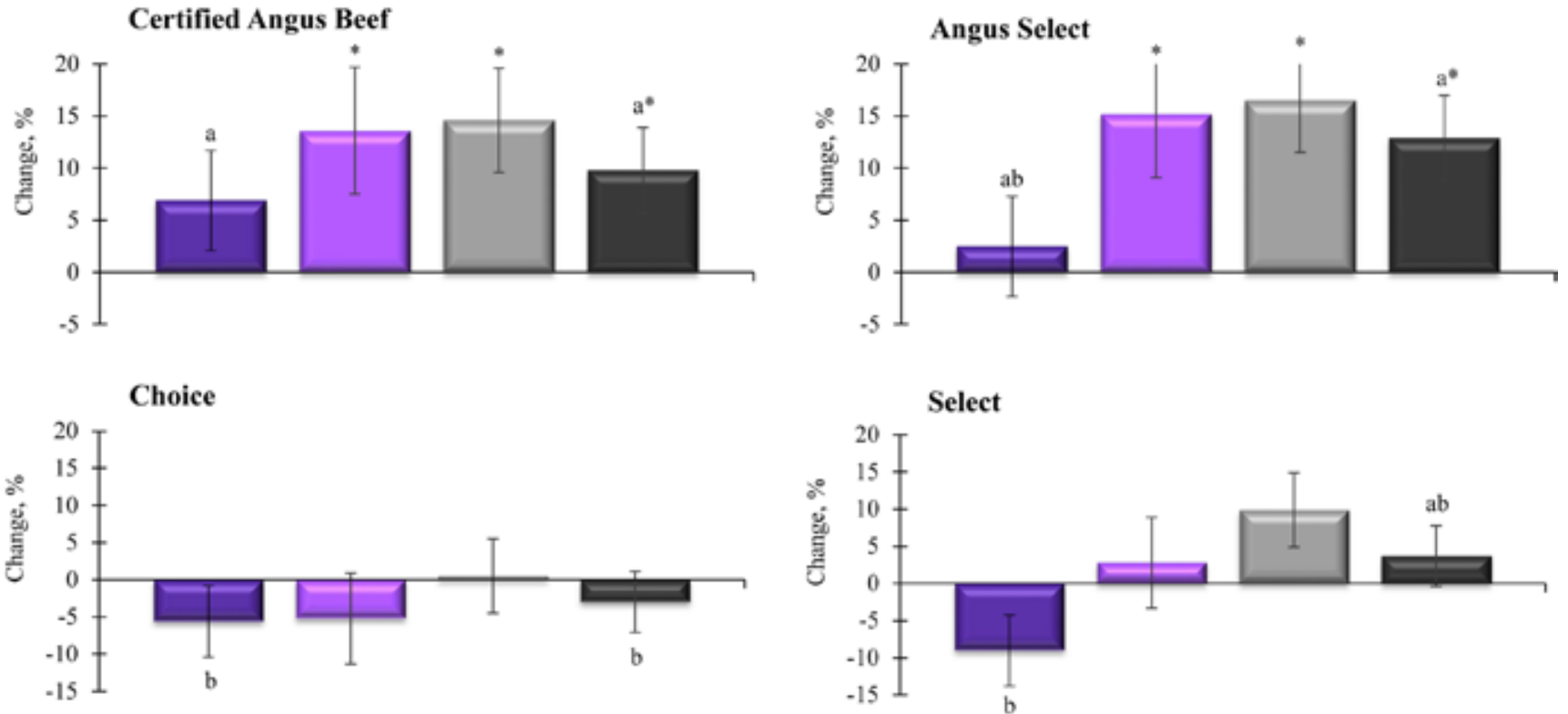

Figure 2. Percentage change ([consumer informed score - consumer blind score $]$ /consumer blind score) in consumer $(n=112)$ ratings of palatability traits due to USDA grade and brand disclosure before sample evaluation. *Mean differs from zero $(P<0.05)$. ${ }^{\mathrm{a}, \mathrm{b}}$ Treatment means for the same palatability trait without a common superscript differ $(P<0.05)$.

$<0.05$ ) for $\mathrm{CAB}$, Prime, and Angus Select samples by $9.8 \%, 12.4 \%$, and $12.9 \%$, respectively. Although Prime, $\mathrm{CAB}$, and Angus Select steaks received increased palatability ratings when brand was informed, Choice and Select samples did not follow the same trend. The observed changes in palatability scores for both Choice and Select steaks were not significantly different $(P>$ $0.05)$ from zero for all palatability traits. Although no changes in tenderness ratings for any brand were different $(P>0.05)$ from zero, Prime and $\mathrm{CAB}$ had greater $(P$ $<0.05)$ increases compared to Select and Choice, with Angus Select rating similar $(P>0.05)$ to all treatments. Additionally, the observed change for overall liking was lower $(P<0.05)$ for Choice than all other treatments other than Select.

\section{Consumer Acceptance of Sensory Traits}

The percentage of samples rated acceptable for each palatability trait during blind and informed testing is presented in Table 6 . The percentage of samples rated acceptable for tenderness was lower $(P<0.05)$ for Angus Select than for all treatments other than Select when steaks were sampled blind. Additionally, Prime had the highest $(P<0.05)$ percentage of samples rated acceptable for juiciness $(92.7 \%)$ compared to all other treatments during blind testing. All treatments other than Prime had a similar $(P>0.05)$ percentage of samples rated acceptable for juiciness. Also, Prime and CAB had a similar $(P>0.05)$ percentage of samples rated as acceptable for tenderness, flavor, and overall liking, with more than $87 \%$ of samples rated acceptable for both treatments for each of these traits when consumers sampled steaks blind. No difference $(P>0.05)$ was found among Choice, Select, and Angus Select treatments for the percentage of samples rated acceptable for juiciness, overall liking, or flavor. Moreover, overall liking was only rated acceptable for $70.5 \%$ of Angus Select samples and $72.1 \%$ of Select steaks. In other words, these treatments failed to meet consumers' overall eating expectations approximately $30 \%$ of the time in blind testing when grade was not informed.

When consumers were informed of the brand of each treatment, a similar $(P>0.05)$ percentage of samples was considered acceptable for tenderness for Prime, $\mathrm{CAB}$, and Choice, whereas only $\mathrm{CAB}$ samples were similar to Prime in blind testing. A higher $(P<$ $0.05)$ percentage of $\mathrm{CAB}$ samples was considered ac- 
Table 6. Percentage of beef strip steaks considered acceptable for tenderness, juiciness, flavor, and overall liking by consumers $(n=112)$

\begin{tabular}{|c|c|c|c|c|}
\hline Treatment & $\begin{array}{c}\text { Tenderness } \\
\text { acceptability }\end{array}$ & $\begin{array}{c}\text { Juiciness } \\
\text { acceptability }\end{array}$ & $\begin{array}{c}\text { Flavor } \\
\text { acceptability }\end{array}$ & $\begin{array}{c}\text { Overall } \\
\text { acceptability }\end{array}$ \\
\hline \multicolumn{5}{|l|}{ Blind testing } \\
\hline Prime & $98.2^{\mathrm{a}}$ & $92.7^{\mathrm{a}}$ & $87.2^{\mathrm{a}}$ & $92.8^{\mathrm{a}}$ \\
\hline Certified Angus Beef & $92.0^{\mathrm{a}, \mathrm{b}}$ & $81.3^{\mathrm{b}}$ & $90.0^{\mathrm{a}}$ & $90.2^{\mathrm{a}}$ \\
\hline Choice & $88.3^{\mathrm{b}}$ & $81.3^{\mathrm{b}}$ & $83.1^{\mathrm{a}, \mathrm{b}}$ & $79.5^{\mathrm{b}}$ \\
\hline Select & $86.4^{\mathrm{b}, \mathrm{c}}$ & $75.7^{\mathrm{b}}$ & $74.9^{\mathrm{b}}$ & $72.1^{\mathrm{b}}$ \\
\hline Angus Select & $75.9^{c}$ & $74.8^{\mathrm{b}}$ & $72.4^{\mathrm{b}}$ & $70.5^{\mathrm{b}}$ \\
\hline SEM $^{1}$ & 4.0 & 4.1 & 5.3 & 4.3 \\
\hline$P$-value & $<0.01$ & 0.02 & $<0.01$ & $<0.01$ \\
\hline \multicolumn{5}{|l|}{ Informed testing } \\
\hline Prime & $95.8^{\mathrm{a}}$ & $98.2^{\mathrm{a}}$ & $97.6^{\mathrm{a}}$ & $99.2^{\mathrm{a}}$ \\
\hline Certified Angus Beef & $95.8^{\mathrm{a}}$ & $90.2^{\mathrm{b}}$ & $95.0^{\mathrm{a}, \mathrm{b}}$ & $93.2^{\mathrm{b}}$ \\
\hline Choice & $90.7^{\mathrm{a}}$ & $75.0^{\mathrm{c}}$ & $87.6^{\mathrm{b}, \mathrm{c}}$ & $86.3^{\mathrm{b}, \mathrm{c}}$ \\
\hline Select & $80.3^{\mathrm{b}}$ & $75.7^{\mathrm{c}}$ & $80.4^{\mathrm{c}}$ & $78.9^{\mathrm{c}}$ \\
\hline Angus Select & $78.2^{\mathrm{b}}$ & $77.6^{\mathrm{c}}$ & $86.6^{\mathrm{c}}$ & $80.8^{\mathrm{c}}$ \\
\hline SEM $^{1}$ & 4.6 & 4.8 & 5.3 & 5.0 \\
\hline$P$-value & $<0.01$ & $<0.01$ & $<0.01$ & $<0.01$ \\
\hline
\end{tabular}

${ }^{\mathrm{a}-\mathrm{c}}$ Least squares means in the same section (blind or informed) of the same column and lacking a common superscript differ $(P<0.05)$.

${ }^{1} \mathrm{SE}$ of the least squares means.

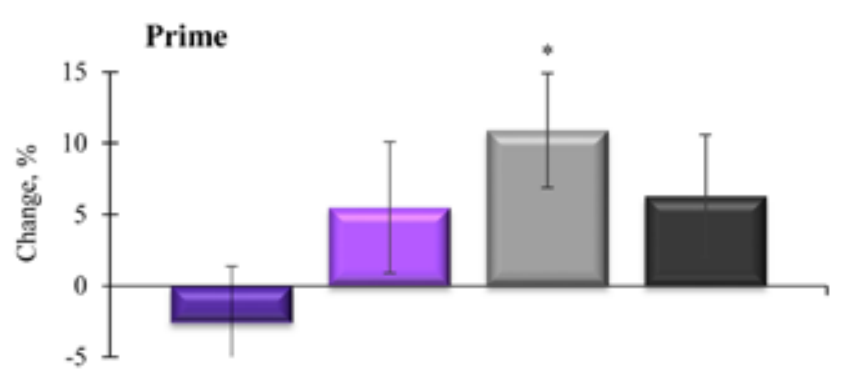

\section{Brand Effect}

Tenderness: $P=0.34$

Juiciness: $P=0.14$

Flavor; $P=0.28$

Overall Liking; $P=0.82$
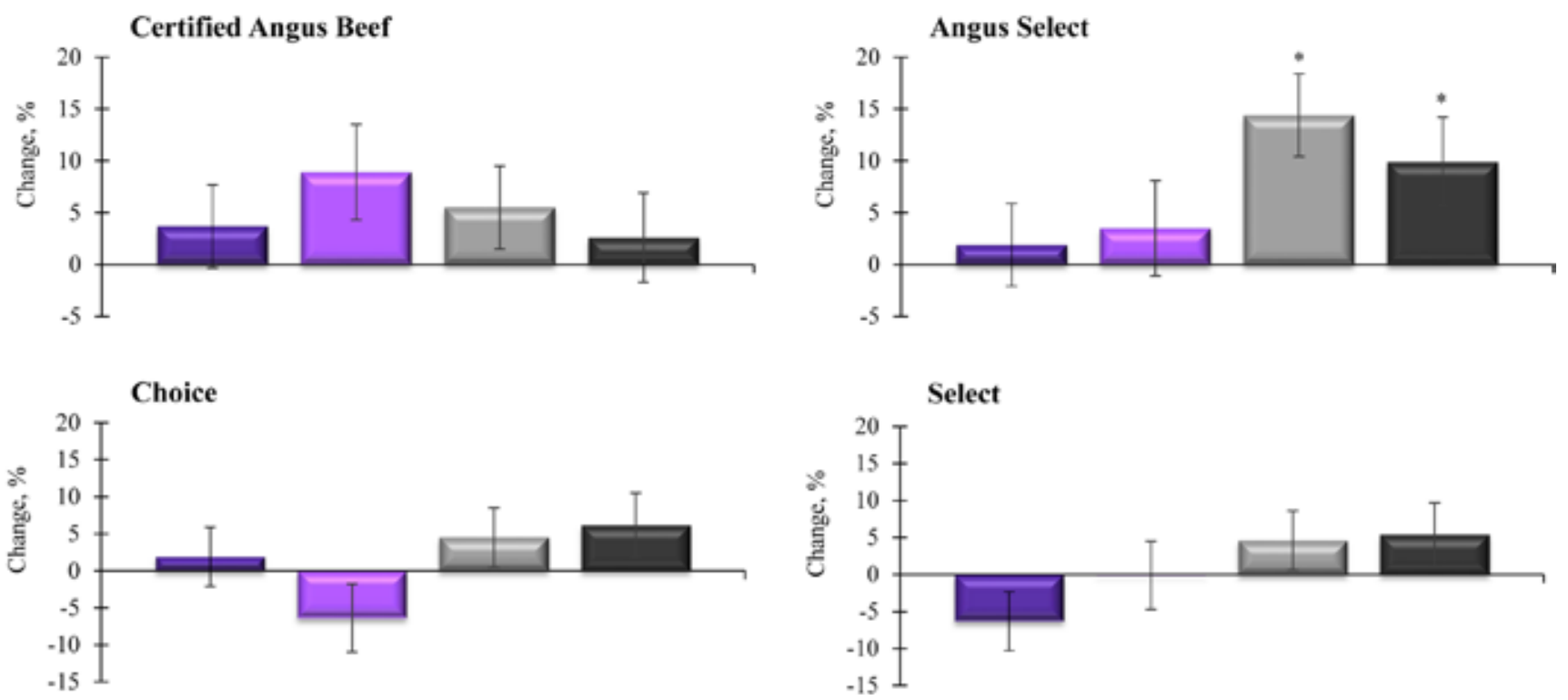

Figure 3. Change in the percentage of beef strip steaks of varying quality treatments considered acceptable for tenderness, juiciness, flavor, and overall liking by consumers $(n=112)$ due to USDA grade and brand disclosure before sample evaluation. * Mean differs from zero $(P<0.05)$. 
ceptable for juiciness compared to all treatments other than Prime. Conversely, in blind testing, the percentage of $\mathrm{CAB}$ samples rated acceptable for juiciness was similar $(P>0.05)$ to that of Choice, Select, and Angus Select. Prime had the greatest $(P<0.05)$ percentage $(99.2 \%)$ of samples rated acceptable for overall liking when brand was disclosed, whereas during blind testing, $\mathrm{CAB}$ had a similar $(P>0.05)$ percentage.

Results for the percentage change in acceptability of each palatability trait for consumer ratings are presented in Fig. 3. No change $(P>0.05)$ was found for $\mathrm{CAB}$, Choice, or Select for the percentage of samples rated acceptable for all palatability traits by consumers. Also, there was no change $(P>0.05)$ in the percentage of samples rated acceptable for tenderness or juiciness for any of the USDA grades and brands. However, the percentage of samples rated acceptable for flavor increased $(P<0.05) 10.9 \%$ for Prime samples and $14.4 \%$ for Angus Select samples. Additionally, consumers considered $9.9 \%$ more $(P<0.05)$ Angus Select samples acceptable for overall liking when the brand was disclosed. Prime and $\mathrm{CAB}$ received few increases in the percentage of samples rated as acceptable for each trait, but these 2 treatments had a high percentage $(>80 \%)$ of samples rated acceptable for each trait during blind testing. Because of the high percentage of samples from these treatments rating acceptable during blind testing, the potential was for only small increases due to brand disclosure.

\section{Perceived Quality of Strip Loin Steaks}

Consumer-perceived quality levels for each treatment during blind and informed testing are reported in Table 7. Fewer $(P<0.05) \mathrm{CAB}$ and Prime samples were rated as unsatisfactory quality compared to Choice, Select, and Angus Select treatments, which all had a similar $(P>0.05)$ percentage rated unsatisfactory during blind testing. Additionally, during blind sampling, fewer $(P<0.05)$ Prime samples were rated as everyday quality by consumers than $\mathrm{CAB}$ and Select samples. Also, more $(P>0.05)$ Prime samples were rated as better than everyday compared to all other treatments except Choice when tested bind. Moreover, Select had the fewest $(P<0.05)$ samples rated as premium quality compared to all other treatments.

When brand was disclosed, no Prime samples were classified as unsatisfactory quality; however, there was no difference $(P>0.05)$ among treatments for the number of samples considered unsatisfactory. During blind testing, Prime, CAB, and Angus Select all had a similar $(P>0.05)$ percentage of samples rated as everyday quality compared to Choice. Conversely, during informed testing, the percentage of samples consid- ered everyday quality was similar $(P>0.05)$ for Prime, $\mathrm{CAB}$, and Angus Select and lower $(P<0.05)$ than that for both Choice and Select. Moreover, there was no difference $(P>0.05)$ in the percentage of samples classified as better than everyday quality during informed testing for any of the treatments. Additionally, when brand or grade was disclosed, Prime had the greatest $(P<0.05)$ percentage of samples considered premium quality, whereas during blind testing, all treatments except Select had a similar $(P>0.05)$ percentage of samples classified as premium quality.

The change in the percentage of samples classified into perceived eating quality levels due to brand disclosure is presented in Fig. 4. The percentage of samples classified as unsatisfactory quality changed only for Angus Select, which had 7.1\% fewer $(P<$ $0.05)$ samples considered unsatisfactory during informed testing. There were $13.5 \%, 19.6 \%$, and $12.5 \%$ fewer $(P<0.05)$ samples classified as everyday quality for Prime, CAB, and Angus Select, respectively, by consumers when brand was disclosed. Conversely, Choice had $14.3 \%$ more $(P<0.05)$ samples rated as everyday quality when consumers were informed of the grade. Few differences were found among treatments for better than everyday quality during informed testing; however, $15.2 \%$ more $(P<0.05) \mathrm{CAB}$ samples were considered better than everyday quality when consumers were aware of the brand. Prime had $18.0 \%$ more $(P<0.05)$ samples considered the highest

Table 7. Percentage of beef strip steaks of varying treatments categorized by perceived eating quality level by consumers $(n=112)$

\begin{tabular}{|c|c|c|c|c|}
\hline Treatment & $\begin{array}{c}\text { Unsatisfactory } \\
\text { quality }\end{array}$ & $\begin{array}{c}\text { Everyday } \\
\text { quality }\end{array}$ & $\begin{array}{c}\text { Better than } \\
\text { everyday } \\
\text { quality }\end{array}$ & $\begin{array}{l}\text { Premium } \\
\text { quality }\end{array}$ \\
\hline \multicolumn{5}{|l|}{ Blind testing } \\
\hline Prime & $2.7^{\mathrm{b}}$ & $36.9^{\mathrm{c}}$ & $42.3^{\mathrm{a}}$ & $17.6^{\mathrm{a}}$ \\
\hline Certified Angus Beef & $4.4^{\mathrm{b}}$ & $54.5^{\mathrm{a}, \mathrm{b}}$ & $27.6^{\mathrm{b}, \mathrm{c}}$ & $13.1^{\mathrm{a}}$ \\
\hline Choice & $13.4^{\mathrm{a}}$ & $42.9^{b, c}$ & $33.8^{\mathrm{a}, \mathrm{b}}$ & $9.6^{\mathrm{a}}$ \\
\hline Select & $15.1^{\mathrm{a}}$ & $63.4^{\mathrm{a}}$ & $19.5^{c}$ & $1.7^{\mathrm{b}}$ \\
\hline Angus Select & $18.7^{\mathrm{a}}$ & $47.3^{\mathrm{b}, \mathrm{c}}$ & $23.1^{\mathrm{b}, \mathrm{c}}$ & $10.5^{\mathrm{a}}$ \\
\hline SEM $^{1}$ & 3.8 & 4.7 & 4.9 & 4.1 \\
\hline$P$-value & $<0.01$ & $<0.01$ & $<0.01$ & 0.02 \\
\hline \multicolumn{5}{|l|}{ Informed testing } \\
\hline Prime & 0.0 & $23.4^{b}$ & 41.0 & $35.0^{\mathrm{a}}$ \\
\hline Certified Angus Beef & 3.4 & $35.1^{b}$ & 42.8 & $18.0^{\mathrm{b}}$ \\
\hline Choice & 7.7 & $57.6^{\mathrm{a}}$ & 30.3 & $4.2^{\mathrm{c}}$ \\
\hline Select & 14.7 & $54.0^{\mathrm{a}}$ & 26.8 & $4.2^{\mathrm{c}}$ \\
\hline Angus Select & 11.2 & $35.1^{b}$ & 33.0 & $19.8^{b}$ \\
\hline SEM $^{1}$ & 3.7 & 5.0 & 4.7 & 5.5 \\
\hline$P$-value & 0.08 & $<0.01$ & 0.06 & $<0.01$ \\
\hline
\end{tabular}

${ }^{\mathrm{a}-\mathrm{c}}$ Least squares means in the same section (blind or informed) of the same column and lacking a common superscript differ $(P<0.05)$.

${ }^{1} \mathrm{SE}$ of the least squares means. 


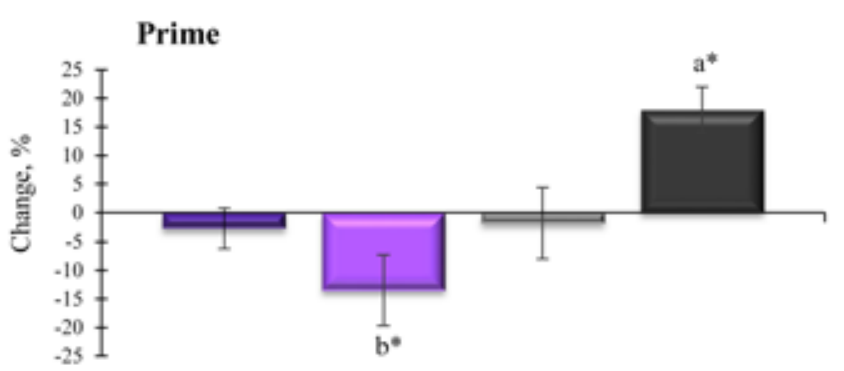

\section{Brand Effect}

Unsatisfactory; $P=0.60$

Everyday; $P<0.01$

Better than Everyday; $P=0.20$

Premium; $P<0.01$

Certified Angus Beef
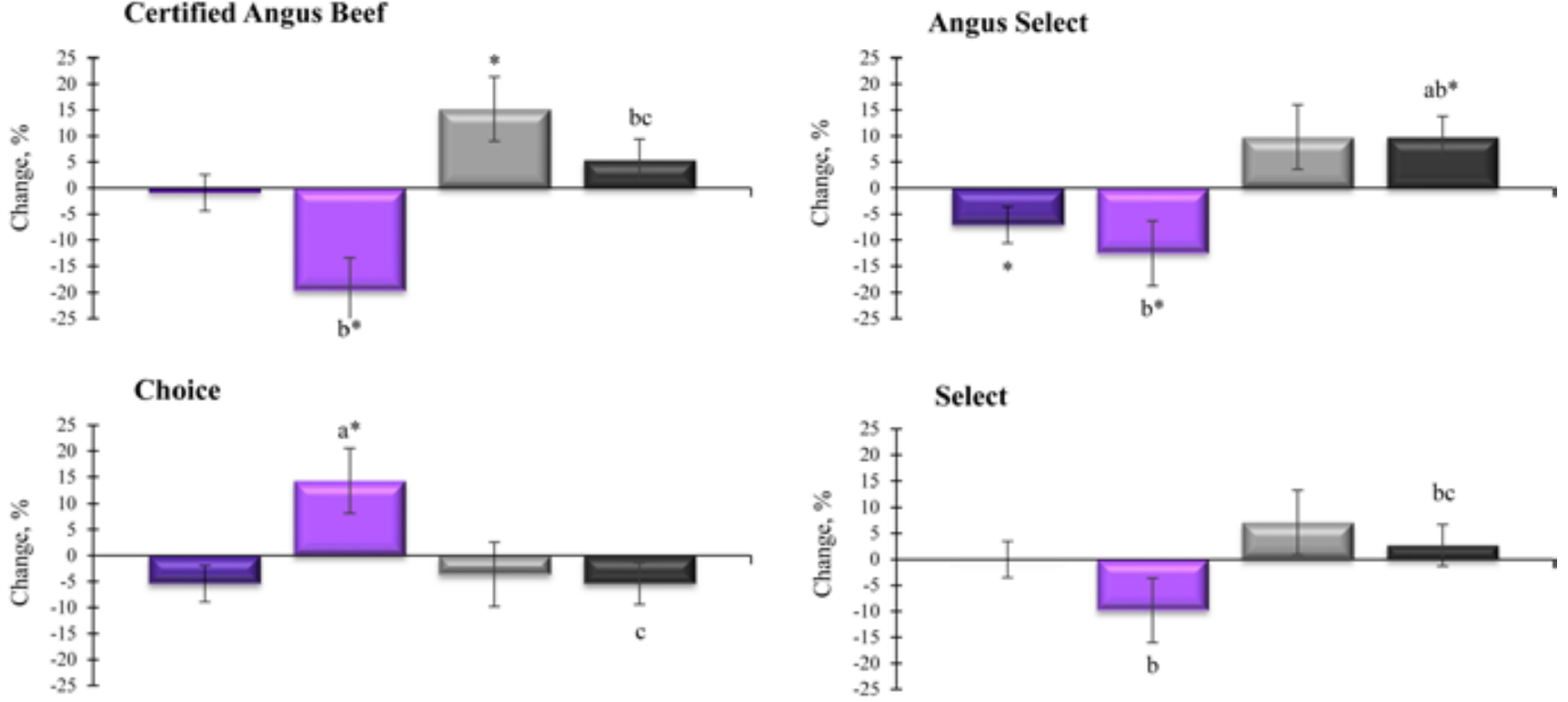

Figure 4. Change in the percentage of beef strip steaks of varying treatments categorized into perceived eating quality levels by consumers $(n=112)$ due to USDA grade and brand disclosure before sample evaluation. * Mean differs from zero $(P<0.05) .{ }^{\text {a-c }}$ Treatment means for the same palatability trait without a common superscript differ $(P<0.05)$.

perceived quality level of premium when grade was disclosed. Also, Angus Select had a clear shift from lower quality perception to higher quality, with $19.6 \%$ fewer $(P<0.05)$ samples rated in the bottom 2 categories of unsatisfactory and everyday quality and $9.8 \%$ more $(P<0.05)$ rated as premium quality due to brand disclosure. Also, Select had no significant $(P>0.05)$ change in perceived quality of any level.

\section{DISCUSSION}

\section{Consumer Demographics, Purchasing Motivators, and Perception of Brands}

Consumers with a wide variety of demographic profiles of varied ages, ethnic origins, household sizes, and income levels were used in this study. This allowed for an evaluation of the effect of branding across a diverse set of consumers with varied backgrounds. Consumers in this study and consumers involved in the study of Lucherk et al. (2016) rated the importance of purchasing motivators similarly, considering steak color, price, and size, weight, and thickness among the most important traits considered when purchasing beef steaks. However, consumers in that study also considered USDA grade to be as important as these traits. Consumers in both the current study and the study of Lucherk et al. (2016) rated intrinsic cues of beef (steak color, size, weight, and thickness, USDA grade, and marbling level) as more important than animal production and product claims. This indicates the increased importance of visual appearance and steak quality to beef consumers compared to production claims presented with products. The current study, as well as others that have demonstrated importance of intrinsic and visual cues of products to consumers (Steenkamp and vanTrijp, 1996; Wachenheim et al., 2000; Robbins et al., 2003; Grunert et al., 2004; Reicks et al., 2011), indicates consumers purchase products primarily on the basis of their visual appearance. However, other studies have reported region of origin as the most important purchasing motivator of beef, with beef from local regions preferred (Mennecke et al., 2007). However, in our study, local was considered less important than many of the quality-related traits. 


\section{Impact of Branding on Consumer Palatability Traits}

Branding of beef is used to differentiate products that meet certain criteria from unbranded or commodity products. Beef branding may provide consumers with information about product quality attributes, animal breed type, production practices, or any number of attributes that may be important to the consumer. Overall, most beef branding strategies provide consumers with an indication of consistency and repeatability of eating experience. Consumers use past experiences and information presented at the time of sale, such as the brand, to form quality expectations before having firsthand experience with a product (Steenkamp, 1990). Beef consumers have identified quality as the most important reason for purchasing branded beef products and perceive branded beef to be more tender and flavorful, thereby offering greater value than unbranded beef (Williams, 2006). Additionally, previous work has indicated consumers with less familiarity with beef use brand as their primary cue of product quality (Bredahl, 2004; Mennecke et al., 2007). Consumers with greater beef knowledge and familiarity are more likely to use intrinsic cues of quality but still rely on brand to give an indication of quality level (Bredahl, 2004; Williams, 2006), indicating that branding plays a large role in quality perception for beef consumers of all knowledge levels.

Numerous authors have detailed the economic impact and benefits of beef branding (Wachenheim et al., 2000; Feldkamp et al., 2005; Parcell and Schroeder, 2007; Froehlich et al., 2009; Schulz et al., 2012; Morales et al., 2013), although to date, the palatabilityrelated value of branding has not been evaluated. The results of the current study suggest that branding has a large impact on perceived eating quality of beef products. Identification of steaks as either $\mathrm{CAB}$ or Angus Select resulted in large increases in consumer ratings of juiciness, flavor liking, and overall liking scores, indicating that these products received a brand lift in palatability due to brand identification. Angus Select steaks also had an increased number of samples rated acceptable for both flavor and overall liking, with more than $10 \%$ more samples rated acceptable overall because of branding. It is interesting to note that Angus Select samples in the current study differed from Select samples in only Angus phenotype and not muscle proximate composition. In blind testing, the 2 treatments were similar for all palatability traits evaluated. However, during informed testing, Angus Select samples were rated higher for both flavor and overall liking. Even when branding the steaks as "Angus" in the simple, generic form used in this study, we observed large increases in consumer palatability perception. Additionally, in our study consumers indicated branded programs with "Angus" as part of the brand name possessed greater quality than Choice, Select, and brands without Angus identification. This consumer association between Angus branding and quality has been documented by other authors as well (Williams, 2006; Mennecke et al., 2007). Taken together, these results indicate the perceived quality level associated with the Angus breed as the likely reason for the increased number of branded beef programs requiring Angus breed characteristics today (USDA, 2016a).

When evaluating the effect of quality grade branding, Prime samples also received a brand lift for flavor liking and overall liking scores, with a greater percentage of samples classified as premium quality, as well as a greater percentage of samples rated acceptable for flavor. During informed testing, more than $95 \%$ of Prime samples were rated acceptable for each palatability trait, with more than $99 \%$ of samples rated acceptable overall. These results underscore the importance of Prime branding for retailers and food service establishments who sell Prime product. In our study, when consumers were aware they were eating Prime steak samples, only a very small percentage $(<1 \%)$ of samples failed to meet consumer eating expectations.

Branding did not have an impact on either Choice or Select samples. Ratings for all palatability traits were unaffected by brand disclosure for these treatments. Additionally, the percentage of samples rated as acceptable for each trait remained unchanged when consumers were informed of the grade. This indicates that both Choice and Select branding provide no benefit to consumer eating quality perception. Consumers in our study identified Choice and Select as 2 of the USDA grades and brands with the lowest perceived quality levels when compared to Prime and multiple branded beef programs. Other authors have indicated consumers are confused by the USDA quality grading system and are unable to correctly identify the quality level associated with each grade (Williams, 2006; DeVuyst et al., 2014). With the large number of retailers that sell Choice and Select beef and market these products under these grade names, it is possible that today's consumers now consider both of these products as "commodity quality" with no perception of added value or eating quality for these 2 grades. This is supported by our current findings and gives further evidence of the added value provided by branded beef programs.

Our results are similar to those for other products that have been tested blind and informed, demonstrating products that are associated with high quality, generally, will be given increased palatability ratings during informed testing. For beef, a recent study found $\mathrm{CAB}$ ground beef products to increase in overall liking ratings by $11 \%$ to $25 \%$ when consumers were informed of the brand prior to sampling (Wilfong et al., 2016). 
Similarly, chicken meat labeled as organic resulted in increased consumer ratings for juiciness and overall liking when compared to identical unbranded samples (Samant and Seo, 2016). Overall liking of beer was reported to increase by $6 \%$ to $21 \%$ when consumers were presented with the bottle information when sampling (Allison and Uhl, 1964). Additionally, informed testing of well-known brands of other food products, including pasta noodles and hazelnut spreads, has demonstrated increased consumer overall liking scores of 7\% to $20 \%$ when compared to blind testing (Di Monaco et al., 2004; Kim et al., 2015; Spinelli et al., 2015). Other authors have reported no benefits of informing consumers of the brand of orange juice, low-calorie biscuits, frozen sweet corn, and hazelnut chocolate bars prior to testing (Carrillo et al., 2012; Szőke et al., 2012; Kim and Lee, 2015), with 1 study finding branding resulted in 15\% lower overall liking scores for pasta noodles (Di Monaco et al., 2004). Our results and previous work indicate that not all USDA grades and brands will receive a lift in eating quality. The degree to which eating quality is affected by brand is proportional to the perceived quality level of the brand. This indicates that palatability-related benefits of branding are not seen for all USDA grades and brands, but only those associated with high-quality products.

\section{LITERATURE CITED}

Allison, R. I., and K. P. Uhl. 1964. Influence of beer brand identification on taste perception. J. Mark. Res. 1:36-39. doi:10.2307/3150054

AOAC. 2005. Official methods of analysis. 18th ed. Assoc. Off. Anal. Chem., Arlington, VA.

Bredahl, L. 2004. Cue utilisation and quality perception with regard to branded beef. Food Qual. Prefer. 15:65-75. doi:10.1016/ S0950-3293(03)00024-7

Carrillo, E., P. Varela, and S. Fiszman. 2012. Effects of food package information and sensory characteristics on the perception of healthiness and the acceptability of enriched biscuits. Food Res. Int. 48:209-216. doi:10.1016/j.foodres.2012.03.016

Corbin, C. H., T. G. O’Quinn, A. J. Garmyn, J. F. Legako, M. R. Hunt, T. T. N. Dinh, R. J. Rathmann, J. C. Brooks, and M. F. Miller. 2015. Sensory evaluation of tender beef strip loin steaks of varying marbling levels and quality treatments. Meat Sci. 100:24-31. doi:10.1016/j.meatsci.2014.09.009

Della Lucia, S. M., V. P. R. Minim, C. H. O. Silva, L. A. Minim, and P. de Aguiar Cipriano. 2014. Use of relative risk test to evaluate the influence of the brand on beer acceptability. Semina Cienc. Agrar. 35:267-276.

DeVuyst, E. A., J. L. Lusk, and M. A. DeVuyst. 2014. The USDA quality grades may mislead consumers. J. Anim. Sci. 92:31423148. doi:10.2527/jas.2014-7581

Di Monaco, R., S. Cavella, S. Di Marzo, and P. Masi. 2004. The effect of expectations generated by brand name on the acceptability of dried semolina pasta. Food Qual. Prefer. 15:429-437. doi:10.1016/j.foodqual.2003.07.003
Feldkamp, T. J., T. C. Schroeder, and J. L. Lusk. 2005. Determining consumer valuation of differentiated beef steak quality attributes. J. Muscle Foods 16:1-15. doi:10.1111/j.17454573.2004.05303.X

Froehlich, E. J., J. G. Carlberg, and C. E. Ward. 2009. Willingness to pay for fresh brand name beef. Can. J. Agric. Econ. 57:119-137. doi:10.1111/j.1744-7976.2008.01141.x

Grunert, K. G., L. Bredahl, and K. Brunsø. 2004. Consumer perception of meat quality and implications for product development in the meat sector-A review. Meat Sci. 66:259-272. doi:10.1016/ S0309-1740(03)00130-X

Kelly, J. 2016. National Meat Case Study 2015. Annu. Meat Conf., Nashville, TN.

Kim, J. Y., S. M. Lee, J.-Y. Kim, and K.-O. Kim. 2015. Influence of intrinsic factors and extrinsic product information on acceptability for Mulnaengmyeon (Korean traditional cold noodle) broth. Food Sci. Biotechnol. 24:1317-1326. doi:10.1007/ s10068-015-0169-x

Kim, M. K., and K.-G. Lee. 2015. Influences of intrinsic and extrinsic factors on consumer acceptance of orange juice using consumer liking testing and Kano analysis techniques. Food Sci. Biotechnol. 24:1687-1693. doi:10.1007/s10068-015-0219-4

Lucherk, L. W., T. G. O’Quinn, J. F. Legako, R. J. Rathmann, J. C. Brooks, and M. F. Miller. 2016. Consumer and trained panel evaluation of beef strip steaks of varying marbling and enhancement levels cooked to three degrees of doneness. Meat Sci. 122:145-154. doi:10.1016/j.meatsci.2016.08.005

Martin, J. N., J. C. Brooks, L. D. Thompson, J. W. Savell, K. B. Harris, L. L. May, A. N. Haneklaus, J. L. Schutz, K. E. Belk, T. Engle, D. R. Woerner, J. F. Legako, A. M. Luna, L. W. Douglass, S. E. Douglass, J. Howe, M. Duvall, K. Y. Patterson, and J. L. Leheska. 2013. Nutrient database improvement project: The influence of USDA quality and yield grade on the separable components and proximate composition of raw and cooked retail cuts from the beef rib and plate. Meat Sci. 95:486-494. doi:10.1016/j.meatsci.2013.05.031

Mennecke, B. E., A. M. Townsend, D. J. Hayes, and S. M. Lonergan. 2007. A study of the factors that influence consumer attitudes toward beef products using the conjoint market analysis tool. J. Anim. Sci. 85:2639-2659. doi:10.2527/jas.2006-495

Morales, L. E., G. Griffith, V. Wright, E. Fleming, W. Umberger, and N. Hoang. 2013. Variables affecting the propensity to buy branded beef among groups of Australian beef buyers. Meat Sci. 94:239-246. doi:10.1016/j.meatsci.2013.02.005

North American Meat Processors Association. 2010. The meat buyer's guide. 6th ed. North Am. Meat Processors Assoc., Reston, VA.

National Cattlemen's Beef Association, National Pork Board, and Sealed Air Corporation. 2010. A snapshot of today's retail meat case: 2010 National Meat Case Study executive summary. Natl. Cattlemen's Beef Assoc., Centennial, CO.

O'Quinn, T. G., J. C. Brooks, R. J. Polkinghorne, A. J. Garmyn, B. J. Johnson, J. D. Starkey, R. J. Rathmann, and M. F. Miller. 2012. Consumer assessment of beef strip loin steaks of varying fat levels. J. Anim. Sci. 90:626-634. doi:10.2527/jas.2011-4282

Parcell, J. L., and T. C. Schroeder. 2007. Hedonic retail beef and pork product prices. J. Agric. Appl. Econ. 39:29-46. doi:10.1017/ S1074070800022732

Reicks, A. L., J. C. Brooks, A. J. Garmyn, L. D. Thompson, C. L. Lyford, and M. F. Miller. 2011. Demographics and beef preferences affect consumer motivation for purchasing fresh beef steaks and roasts. Meat Sci. 87:403-411. doi:10.1016/j.meatsci.2010.11.018 
Robbins, K., J. Jensen, K. J. Ryan, C. Homco-Ryan, F. K. McKeith, and M. S. Brewer. 2003. Consumer attitudes towards beef and acceptability of enhanced beef. Meat Sci. 65:721-729. doi:10.1016/S0309-1740(02)00274-7

Samant, S. S., and H.-S. Seo. 2016. Quality perception and acceptability of chicken breast meat labeled with sustainability claims vary as a function of consumers' label-understanding level. Food Qual. Prefer. 49:151-160. doi:10.1016/j.foodqual.2015.12.004

Savell, J. W., R. E. Branson, H. R. Cross, D. M. Stiffler, J. W. Wise, D. B. Griffin, and G. C. Smith. 1987. National consumer retail beef study: Palatability evaluations of beef loin steaks that differed in marbling. J. Food Sci. 52:517-519. doi:10.1111/j.1365-2621.1987.tb06664.x

Schulz, L. L., T. C. Schroeder, and K. L. White. 2012. Value of beef steak branding: Hedonic analysis of retail scanner data. Agric. Resour. Econ. Rev. 41:260-273.

Spinelli, S., C. Masi, G. Zoboli, J. Prescott, and E. Monteleone. 2015. Emotional responses to branded and unbranded foods. Food Qual. Prefer. 42:1-11. doi:10.1016/j.foodqual.2014.12.009

Steenkamp, J. B. E. M. 1990. Conceptual-model of the quality perception process. J. Bus. Res. 21:309-333. doi:10.1016/01482963(90)90019-A
Steenkamp, J. B. E. M., and H. C. M. vanTrijp. 1996. Quality guidance: A consumer-based approach to food quality improvement using partial least squares. Eur. Rev. Agric. Econ. 23:195-215. doi:10.1093/erae/23.2.195

Szőke, A., V. Losó, L. Sipos, A. Geösel, A. Gere, and Z. Kókai. 2012. The effect of brand/type/variety knowledge on the sensory perception. Acta Aliment. 41:197-204. doi:10.1556/ AAlim.41.2012.Suppl.19

USDA. 2016a. Comparison of certified beef programs. http://www.ams.usda.gov/sites/default/files/media/ LSCertifiedBeefPrograms Comparison060315.pdf. (Accessed 15 July 2016.)

USDA. 2016b. USDA specification for characteristics of cattle eligible for approved beef programs claiming Angus influence. USDA, Washington, DC.

Wachenheim, C. J., C. Alonso, and M. Dumler. 2000. Marketing a branded fresh beef product. J. Food Prod. Mark. 6:53-79. doi:10.1300/J038v06n01_05

Wilfong, A. K., K. V. McKillip, J. M. Gonzalez, T. A. Houser, J. A. Unruh, E. A. E. Boyle, and T. G. O'Quinn. 2016. Determination of the effect of brand and product identification on consumer palatability ratings of ground beef patties. J. Anim. Sci. doi: 10.2527/jas.2016-0894

Williams, L. E. 2006. Consumer perceptions of branded beef products. Master's Thesis. Univ. of Tennessee, Knoxville. 